\title{
Analysis of The Bali Province Role of Komisi Pemilihan Umum Towards Increasing Political Participation of Bali Private Voters in Bali Province Head Election 2018
}

\author{
I Made Wimas Candranegara ${ }^{1}$, I Dewa Gede Putra Sedana ${ }^{2}$, I Nyoman Mangku Suryana ${ }^{3}$ \\ \{wimascandranegara3491@gmail.com ${ }^{1}$, putrasedana1967@gmail.com ${ }^{2}$, mangkusuryana@yahoo.co.id ${ }^{3}$ \} \\ Lectures in Public Administration Department, Faculty of Social and Political, \\ Warmadewa University ${ }^{123}$
}

\begin{abstract}
The role of the Bali Provincial Komisi Pemilihan Umum (KPU) as an election organizer includes socialization and administrative services. The problem of this research is how is the role of the General Election Commission of the Province of Bali against the increase in political participation of the beginner voters in the election of the regional head of Bali Province in 2018. The purpose of the research is to determine the role of the General Election Commission of the Province of Bali against the political participation of the beginning voters in the election of the Bali Province 2018 This research was conducted using qualitative research methods consisting of 3 (three) paths, namely data reduction, data presentation and verification. Based on the data analysis, it is stated that the role of the KPU of Bali Province conducted by KPU of Bali Province to the community is good enough. This can be seen from the role of the Bali Provincial Election Commission in the Pemilukada 2018. The Political Participation of Beginner Voters in the Election is segmentation, socialization, political information, voting rights. Some suggestions can be proposed which are expected to improve the implementation of good socialization, namely, KPU Bali Province needs to be faster in conducting socialization to the beginner voters to achieve the desired goals, namely community satisfaction. In addition, the KPU of Bali Province needs to provide an opportunity for voters to oversee the voting process in post-conflict local elections. It is necessary for new voters to be registered as voters in post-conflict local elections. Need to involve new voters to take part in the socialization carried out by the KPU of Bali Province.
\end{abstract}

Keywords: Political Participation, Beginner Voters.

\section{Introduction}

If a country places the people as voters. The people are an important component in the state of the highest sovereignty in the hands of the people. Indonesia as a democratic country, states that power is in the hands of the people. The fourth Alinia opening of the 1945 Constitution states that, "The Republic of Indonesia which has sovereignty" is then more explicitly stated in the body of the 1945 Constitution, article 1 paragraph (2) which reads, "Sovereignty is in the hands of the people and is carried out entirely by the People's Consultative Assembly, after the third amendment of the 1945 Constitution took place on 10 November 2001, article 1 paragraph (2) reads "Sovereignty is in the hands of the people and 
carried out according to the Constitution, from the results of the amendment it is explained that the implementation of popular sovereignty is no longer carried out by an institution.

Political participation of the community in the election of regional heads is one form of activity that aims to influence political decision making. Political participation is meant to position the community as citizens (voters) not as politicians (chosen). The direct election of the regional head with the democratic process makes the people the legitimate owners to participate in determining their choices. People who are considered sovereignty holders participate in the political process which can be seen from participating in voting in the elections.

Political participation of the community is one of the supporting factors for the implementation of regional head elections. The level of community participation at the time of the regional head election becomes part of an ideal benchmark for a democracy. Community enthusiasm to engage in political participation shows that democracy is progressing. This proves that there is a higher political awareness of the community. The high level of community participation shows that people understand the importance of political issues and are moved to take part in the process of political democracy. But on the contrary, if the participation of the people is low, it shows the community's disregard for the state problem.

In order for the implementation of regional head elections to produce a democratic government and obtain legitimate legitimacy from the people, an independent institution is needed as the organizer of the selection of regional heads. Election administration as stipulated in article 5 of Law No. 15 of 2011 concerning the holding of elections, the organizers consisted of the General Election Commission and the General Election Supervisor as a single function of the election administration.

In this case the organization of election of regional heads is carried out by the Provincial KPU to carry out the gubernatorial election. While the regency / city KPU organizes the election of regents and mayors and their representatives. Given the importance of community participation in the election of regional heads and the ideal benchmark of democracy, the KPU has a role to encourage the community to participate in the implementation of regional elections. Law of the Republic of Indonesia number 10 of 2016 concerning the second amendment to Act No. 1 of 2015 concerning the stipulation of government regulations in lieu of Law No. 1 of 2014 concerning the election of governors, regents and mayors into law, stating that Regency KPUs have duty and obligation to carry out socialization and convey information on election administration to the community. Dissemination of election administration is the process of delivering information about election administration. Election dissemination to increase community political participation is done through political education to the community, especially for voters.

The Province of Bali is one of the regions that held the regional head elections in 2018. The KPU of the Province of Bali has the task of increasing the political participation of the people of the Bali Province. The effort to increase political participation carried out by KPU Bali Province is by conducting socialization and political education.

The number of regional head voters in 2018 the number of voters in Bali Province as in the final voter list (DPT) totaled 2,982,201 voters. In that year the figure of political participation in the regional head elections of the Province of Bali reached 2,103,005 with participation of $70.5 \%$.

Efforts to increase the political participation of the community and reduce the number of abstentions have actually been carried out with the socialization of new voters by the KPU of Bali Province. But on the other hand the community asked the organizers to be more creative and active in disseminating information so that efforts to increase community 
participation in the election were increasing. Because ideally, the increasing age of democracy, the higher the level of political participation should be.

Based on the above, the researcher intends to conduct research with the title "Analysis of the Role of the General Election Commission of the Province of Bali Against the Increasing Political Participation of Beginner Voters in the Election of the Bali Provincial Heads in 2018".

\section{Research Methods}

This research is a sampling study that is research conducted by not investigating all situations or events. The study unit is a particular unit that is calculated as the object of research, so in this study the study unit is the Regency / City of Denpasar, with the number of voters in 2018 as many as 283,119 voters. The population is the beginner voters in 2018 totaling 6,524 voters.

Thus, the sample taken from this study is the first voters in the 2018 post-conflict local election in Denpasar City, which were taken in 4 Districts, namely in North Denpasar, East Denpasar, South Denpasar and West Denpasar Sub districts in each sub district. there is potential to answer each researcher question related to the title. Sample amounts to 100 people who will be directly involved in organizing regional elections against the political participation of novice voters in the Pemilukada of Bali Province in Denpasar City. While the data collection techniques carried out include observation, questionnaires, interviews and documentation. 


\section{Result and Discussion}

Interview results on the role of the Bali Provincial Election Commission on the political participation of new voters in the Bali Province Regional Head General Election in Denpasar City.

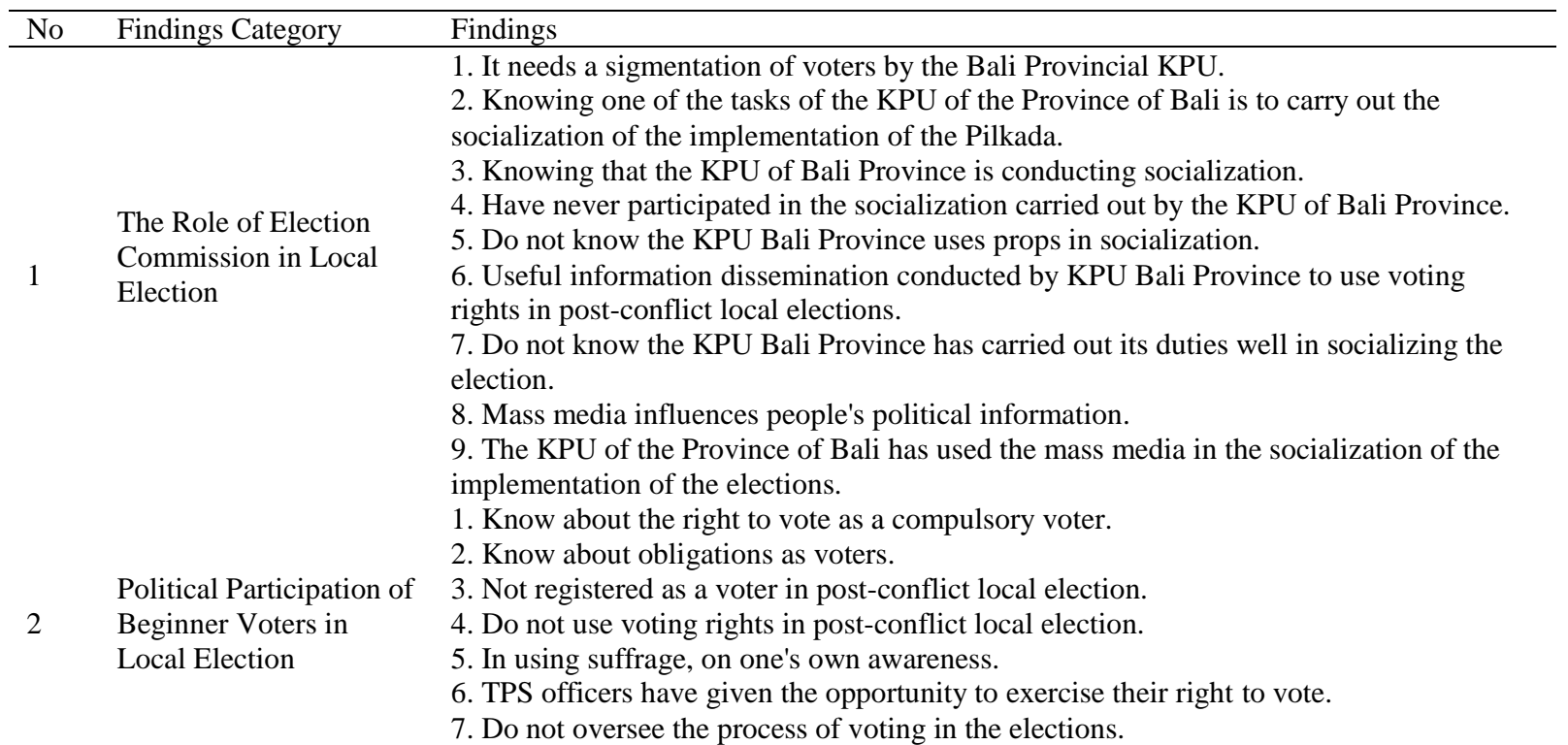

\subsection{Conclusion or Verification}

Data verification activities and conclusions about the role of the KPU of Bali Province on the political participation of new voters in the Bali Provincial Head General Election in Denpasar City. Is one of the implementing agencies at the regional level in the national structure that is responsible and authorized in carrying out provincial elections. Good service can be felt by the community when the Bali Provincial Election Commission which has the authority can carry out its duties and functions.

a. The Role of KPU in Bali Province in the General Election of Regional Heads.

KPU according to Law Number 12 of 2003 concerning Election is the executor and also the supervisor of the election. KPU is supposed to be the organizer which in the concept of implementation includes understanding and supervision. Therefore, the KPU as the organizer simply has to function as a policy maker and regulator. Whereas for the election implementation the KPU forms an Election Implementation Committee, and for supervision by the KPU, an Election Oversight Committee (Panwaslu) can be formed. Both the electoral management committee and the election supervisory committee are ad hoc, formed by and responsible to the KPU, and members and leaders are appointed and dismissed by the KPU

b. Political Participation of Beginner Voters in Local Election.

Every democratic event or general election held by the region has an impact on the development of progress in the life of the nation and state. The political elites actually 
provide intelligent political education to the community so that the awareness of democracy is increasingly high from various circles. This democratic awareness is high if community participation in giving their rights is also high. Therefore, public awareness to participate positively in the existing political system, if someone feels himself in accordance with the environment where he is. If the conditions that occur are the opposite, then there will be political attitudes and behaviors that appear awkward or negative, for example if someone is used to being in a democratic political environment, but he is placed in a feudal or undemocratic society, he will experience difficulties in the process of adapting.

Increasing community involvement in the implementation of the General Election (Election), shows the strength of the democratic order in a country. Democracy requires the involvement of the people in every administration carried out by the state. The people are positioned as important actors in the democratic order, because in essence democracy is based on the logic of equality and the idea that the government needs approval from the governed. Community involvement is a basic element in democracy. For this reason, the holding of elections as a means of carrying out democracy, of course cannot be separated from the involvement of the community.

Political participation goes hand in hand when the political process runs stably. Often there are obstacles to political participation when political stability cannot be realized, because it is important to be carried out by the power holders to carry out the process of political stabilization. Besides that, the next process is to make efforts to institutionalize politics as a form of efforts to provide opportunities for the community to actualize their ideals.

Political participation is not more than the involvement of individuals to various levels, or is also explained substantially can mean efforts or efforts organized by constituents or good citizens to choose leaders they value well. This participation they do with full responsibility towards the common life within the scope of a nation and state. Political participation is emphasized on aspects to support the interests or vision and mission of the political elite.

As a wise society we must participate in the electoral process in order to determine the leaders who lead us. As such, we indirectly determine policy makers who seek public welfare in general. In participating in the electoral process as an intelligent society we must be able to assess the best candidates who are able and willing to listen to the aspirations of the community so that the development is carried out in accordance with the wishes of the community and does not choose candidates who only concern themselves or their groups so that they forget their promises. promises that have been said during the campaign period. As the owner of voter rights in the election, we should not waste our voting rights only for temporary lure, which means that we have to give our votes to the right candidates. Our nonparticipation actually makes us difficult because we do not participate but must follow leaders we do not choose. Voters' participation in the implementation of the General Election is absolutely necessary, without voter participation, the Election is only to make it as a mere object and one of its criticisms is when the community does not feel possessed and indifferent to the general election. 


\section{Conclusion}

As generally, the final step in the flow of research activities is to draw conclusions. The conclusions described are inseparable from the discussion in the previous chapter, conclusions can be drawn in the research Analysis of the Role of the General Election Commission of the Province of Bali Against Political Participation of Beginner Voters in the Election of Bali Province Regional Heads in Denpasar City as follows:

4.1 The role of the KPU in the Province of Bali in the General Election of Regional Heads. Based on the results of the study, that the KPU of Bali Province had carried out what was its role, namely to conduct socialization to the beginner voters by using mass media and teaching aids to explain the election to first-time voters, because socialization is very useful for beginner voters can use their rights as compulsory voters.

4.2 Participation of first-time voters in the elections has used their rights as compulsory voters and participated in the election after being registered as a compulsory voter on their own awareness without coercion from other parties, because TPS officers provide voters with the right to vote.

Based on the conclusions from the results of the research that has been stated above, the researchers provide suggestions that are expected to increase the role of the KPU in the Province of Bali in Denpasar.

a. It is necessary for the KPU of the Province of Bali to provide an opportunity for voters to oversee the process of voting in the elections.

b. Need for new voters to use their voting rights in post-conflict local elections in Denpasar City.

c. Need to begin voters registered as voters in post-conflict local elections.

d. KPU needs Bali Province to use teaching aids in socialization.

e. It is necessary to involve new voters to take part in the socialization carried out by the KPU of Bali Province.

\section{References}

[1] Anggara, S.: Indonesian Political System. CV Setia Pustaka, Bandung (2013)

[2] Arikunto, S.: Research Procedure. PT Rinek Cipta Batawi, Jakarta (2013)

[3] Antulian, R.: Politics of money in the way of regional head elections. Ghalia Indonesia, Jakarta (2004)

[4] Budiardjo.: Basics of Political Science. PT. Gramedia Main Library, Jakarta (2008)

[5] Damsar.: Introduction to Political Social Sciences. Kencana, Jakarta (2012)

[6] Donald, P.: Sued the ELECTION. Library of Sinar Harapan, Jakarta (1997)

[7] Hidayat, K., \& Kleden, I.: Political Party Struggle in Indonesia. PT. Rajawali Perss, Jakarta (2004)

[8] Tarjih Journal and Development of Islamic Thought. 2004. National Leadership \& Good Governance. 8th Edition, July 2004 / Jumadil Ula 1425 H. Yogyakarta.

[9] Juliansyah, E.: ELECTION: Organizing Elections of Regional Heads and Deputy Regional Heads. Bandung: Mandar Forward (2007)

[10] J.W. 2013. "Level of Political Awareness of Beginner Voters in Election", UNIERA Vol 2 Journal No. August 2, 2013.

[11] Mos'oed, M., \& MacAndrews, Colin.: Comparison of Political Systems. Gadjah Mada University Press, Yogyakarta (2008)

[12] Mufti, M.: Political Theories. Faithful library, Bandung (2012)

[13] Syafiee, I.K.: Indonesian Government System (MKDU). PT. Rineka Cipta, Jakarta (1993) 
[14] Yunizir.: Political Education of Citizens in Creating Quality Democracy.Kantaprawira. Vol. 2 (2009)

[15] Rusadi.: Indonesian Political System: An Introduction Model. Political. PT. Rineka Cipta, Jakarta (2006)

[16] Rush, M., \& Althoff, P.: Introduction to Political Sociology. Rajawali Press, Jakarta (2011)

[17] Saragih, T.M.: The Concept of Community Participation in Establishing Regional Regulations on Spatial and Regional Detail Plans. Sasi Journal. Vol. 17(3) (2011)

[18] Satries, W.I.: Measuring the Level of Community Participation in Bekasi City in APBD Preparation through the Implementation of the 2010 Musrenbang. Kybernan Journal. Vol. 2 (2010)

[19] Setiawan, D.: Research Methodology. UNIMED 60 (2014)

[20] Sugiyono.: Qualitative Quantitative Research Methods and R \& D. Alfabeta, Bandung (2010)

[21] Surbakti, Ramlan. 2013.

[22] Tirtarahardja, U., \& Sulo, L.: Introduction to Education. PT Rineka Cipta, Jakarta (2005)

[23] Wahyudi, H.: The Role of Political Trust and Democratic Satisfaction on Student Political Participation. Journal of Psychology. Vol. 9(2) (2013)

[24] Jupiter.: Participation in Community Politics Against Government Policy in Tolikara Regency, Papua Province. Vol. 1(3) (2013)

[25] Undang-Undang No.2 Tahun 2011 Tentang Partai Politik

[26] Undang- Undang No. 15 Tahun 2011 tentang penyelengaraan pemilu, penyelengaraan terdiri dari Komisi Pemilihan Umum dan Pengawas Pemilihan Umum sebagai satu kesatuan fungsi penyelengaraan pemilu

[27] Undang-undang Nomor 3 Tahun 1999 tentang Pemilihan Umum

[28] Keputusan Presiden Nomor 16 Tahun 1999 tentang Pembentukan Komisi Pemilihan Umum dan Penetapan Organisasi dan Tata Kerja Sekretariat Umum Komisi Pemilihan Umum

[29] Undang-undang (UU) Nomor: 32 tentang Penjelasan Pemerintahan Daerah

[30] Peraturan Pemerintah (Pp) Nomor: 17 Tentang Perubahan Atas Peraturan Pemerintah Nomor 6 Tahun 2005 Tentang Pemilihan, Pengesahan Pengangkatan, dan Pemberhentian Kepala Daerah dan Wakil Kepala Daerah

[31] Undang-undang Nomor 22 Tahun 2007 Tentang Penyelenggara Pemilu diatur mengenai penyelenggara Pemilihan Umum yang dilaksanakan oleh suatu Komisi Pemilihan Umum 